\title{
Autopsy Review of Gunshot Deaths in A South Eastern Tertiary Hospital of NIGERIA FROM 2008-2012
}

\author{
Nnoli M.A ${ }^{1}$, Nwabuko C.O. ${ }^{2}$, Nnoli Chinenye ${ }^{3}$ \\ ${ }^{I}$ Dept Of Pathology and Forensic Medicine, University Of Calabar. Nigeria \\ ${ }^{2}$ Dept Of Haematology, Federal Medical centre,Umuahia.Nigeria \\ ${ }^{3}$ Dept of Paediatrics, University of Uyo.Nigeria
}

\begin{abstract}
Aims and Objectives: To evaluate incidence of deaths following gunshot injuries with the resultant lesions.Materials and Method: A cross-sectional study of all incidence of gunshot injuries spanning from 20082012 were extracted from the coroner forms of all autopsy carried out during these period. A total of 30 cases of various age were obtained and by a statistical assessment placed according to age range. The sex ratio was evaluated and various injury/lesions also noted after a detailed forensic autopsy. A pre-designed program was used to record data. Data collected were organized, tabulated and statistically analyzed on Spss version 16.

Results: It was observed that age range of 21-30 years (33\%) are more affected followed by 31-40 years (26.7\%). The gender more affected are males accounting for $82.8 \%$. Also the extent of injuries /lesions of more are multiple soft tissue and skeletal injuries which is 33\%; closely followed by massive exsanguinations (25\%).

Conclusion: Gunshot injuries is more common form of trauma leading death in our environment with very young, productive age of the society affected hence there is a greater need for effective law guiding acquisition and a good disaster victim team investigation; with forensic pathologist heading it.
\end{abstract}

Keywords: Gunshot, Medico-legal Autopsy, Death

\section{Introduction}

Despite stringent legislation in some developed nations like united-kingdom and world over use of firearms in criminals activities continue to increase. Weapons are becoming cheaper and easier to obtain as a result of excessive and at times indiscriminate supply of arms and ammunition by governments and acts or actions of natural; and international terrorist groups. ${ }^{1}$ In all part of the world, deaths due to gunshot injuries continue to increase tremendously. ${ }^{2}$ This is also seen in Pakistan as this is the best mode of committing murder. ${ }^{3,45}$ Firearms have served as most destructive useful weapons in our modern day society. These have functioned in ensuing high cases of fatalities world wide. ${ }^{6}$ However differences exist all over the world but the incidence is highest in developing and lower income countries. ${ }^{7}$ At the moment New Zealand, is known to be one of the safest countries in the world. ${ }^{8}$ Gunshot wounds (GSW) in New Zealand cities are very uncommon compared with major cities world-wide. Although,crimes do exist but most GSW are mostly accidental or self inflicted injuries. The low level in this part of the world is largely due to the occupation of the people which is farming and hunting. Since GSW are uncommon here, the specialists/trainees have little knowledge and exposure to their management hence this leads to high fatalities in event of occurrence

The severity of gunshot injuries is determined by the damage of the tissues caused by the mechanical interaction between the bullet and tissues, and effects of the cavity produced by the bullet. ${ }^{9}$ The evaluation of the injured though still alive requires specialized emergency traumatologist or at death by a forensic pathologist. This is because of the growing trend of indiscriminate use of firearms on a large scale, especially in the last decade. The availability of these firearms-small arms and high weapons (SALW) has been described as a cancer spreading across the developing world. ${ }^{10}$ One of the possible causes for the development of locally made guns is that these weapons are very cheap and readily available for criminals. These types of firearms are manufactured without any fixed standards as production is poor and fired cartridges can easily be distinguished by distinct markings found on it. Also are not known for long distance; and material used is of cheaper quality. ${ }^{11}$

There is a powerful correlation between the acquisition of a gunshot and its use in suicides, murders, assaults and unintentional deaths. As a result of the invention of more advanced gun types and availability, there has been dramatic increase in death rates due to gunshot injuries. ${ }^{12}$ Additionally, in high income countries a significant number of gunshot wounds are related to suicide attempts. ${ }^{13}$

More disturbing are findings that these firearms violence is borne by the most productive segment of the society, that is age range of 15-44 years, males more than females with wide ratio. ${ }^{14}$ Deaths from firearms have been on increase in developing countries ${ }^{15}$ which has been due to spates of communal and ethnic clashes, political violence and armed robberies. ${ }^{16}$ wars in and around west African region have increased easy acquisition to sophisticated and locally manufactured firearms leading to increased incidence of gunshot injuries in peace times through armed violence. ${ }^{17}$ 
This study is taken to document our experience and associated consequences with respect to morbidities due to gunshot injuries in order to advance ways of curbing the growing trends.

Materials and Method: A cross-section of all autopsies done from 2008-2012 was evaluated and that due to gunshot deaths were extracted from the medico-legal (coroner) files. A total of 30 cases of various ages and sex were documented. The data obtained were analyzed using SPSS version 16. Most of the cases warranted our appearance in court as expert witness.

Results:

GUNSHOTS DEATHS IN A SOUTH EASTERN TERTIARY HOSPITAL FROM 2008-2012

\begin{tabular}{|c|c|c|}
\hline \multicolumn{3}{|l|}{ AGE INCIDENCE } \\
\hline AGE GROUP (YEARS) & NO OF CASES & PERCENTAGES \\
\hline $0-10$ & 3 & $10 \%$ \\
\hline $11-20$ & 5 & $16.66 \%$ \\
\hline $21-30$ & 10 & $33 \%$ \\
\hline $31-40$ & 8 & $26.6 \%$ \\
\hline $41-50$ & 4 & $13 \%$ \\
\hline TOTAL & 30 & Average: $100 \%$ \\
\hline
\end{tabular}

\begin{tabular}{|c|c|c|}
\hline \multicolumn{3}{|c|}{ SEX RATIO } \\
\hline SEX & NO OF CASES & PERCENTAGES \\
\hline MALE & 24 & $82.8 \%$ \\
\hline MALE & 5 & 17.2 \\
\hline TOTAL & 29 & $100 \%$ \\
\hline
\end{tabular}

\begin{tabular}{|c|c|c|}
\hline \multicolumn{3}{|l|}{ TYPES OF INJURY/LESION } \\
\hline TYPES OF LESION & NO OF CASES & PERCENTAGES \\
\hline Hypervolemic Shock & 1 & $2.5 \%$ \\
\hline Massive exsanguination & 10 & $25 \%$ \\
\hline Neurogenic shock & 2 & $5 \%$ \\
\hline Intracellular haemorrhage & 6 & $15 \%$ \\
\hline Subarachnoid haemorrhage & 3 & $7.5 \%$ \\
\hline Multiple soft tissues/skeletal injuries & 13 & $33 \%$ \\
\hline Haemothorax & 6 & $15 \%$ \\
\hline
\end{tabular}

Discussion: They were a total of 30 cases autopsied during this period as inquest was given for a detailed medico-legal autopsy. Most of the undocumented and no inquest were treated as clinical autopsy. Some others were not done as the relatives appeared unreceptive in signing concept since there was no inquest from the coroner. Also they are handicapped by lack of will and finances to seek a legal action.

However, age range of 21-30 and 31-40 years which is the more productive age accounted for $33 \%$ and $26.7 \%$ as they are the most devastatedly affected as the study of Houry et al hold same view. Also we noticed the great preponderance of the males affected mostly accounting for $82.8 \%$ (Table 2). Mohammed A.Z et al study in the North central part of Nigeria has same male dominant with a wide ratio when compared with the females. ${ }^{18}$ Azam Khan Khetran et al attributed the increased in male victims to long-term hostility in Pakistan. ${ }^{19}$ Intracerebral haemorrhages and haemothorax were both $15 \%$ as these appeared to be the third prominent sudden death. This is also a prognostic factor seen with Martins $\mathrm{R}$ et al where they attributed a few of gunshot injuries to head having a high mortality with features of low Glasgow coma scores, pupil dilatation, transhemispheric or bihemispheric trajectories and multiple lobar wounds as these are predictors of high mortality and morbidity. ${ }^{20}$ These also is noticed by Emmanuel o. Ojo that instant death results from exsanguinations following haemorrhagic shock. ${ }^{21}$

The type of lesions seen which led to death was evaluated. We noticed that multiple soft tissue and skeletal injuries accounted for 33\%; followed by massive exsanguinations. In Brazil, Falbo et al pointed the fact that most frequent anatomical site leading to exsanguination is lower limbs followed by the chest, upper limbs and head. $^{22}$

Finally the age range of 0-10 years three (3) cases were seen and are all accidental discharge/intentional from armed robbers attack to families. This accounted for $10 \%$ of the study population. 
Limitations: In most cases, we are not aware of the type of firearms used as even when we get some of the sophisticated bullets there are no specialist ballistic to analyzed such. Also the fact of local arms used we could only see the lead pellets scattered; at least we could only make out the fact that it's a local arms used. In few cases, we were able to see the golden cap with plastic red part and that gave us a clue of the firearm used.

Also unwillingness of most people to address their cases at a law court even when the suspects are held. They avoid such procedures giving reasons of let us just bury our deceased since any law suit can not bring him/her back; and at times due to financial unavailability they feel reluctant in pursuance of justice.

Conclusion: Since gunshot injuries is a major cause of mortality and morbidity in this part of Nigeria its now of great interest to address a lot of issue ranging from good qualitative education, unemployment, hard drug abuse and of utmost important respect to human life. More rigid implementation is law guiding acquisition of arms given the most stringent measure.

Training and re-training of Emergency physicians, Neurologist and effective disaster victim team headed by a seasoned forensic pathologist.

\section{References:}

[1]. Richard Shepherd: Simpson's Forensic Medicine 12 edition Chapter 11 Pg 79.

[2]. Rawson B. Aiming for Prevention: Medical and Public Health approaches to small arms, gun violence and injury. Croat Med J 2002; 4: 379-85.

[3]. Miller M, Azrae ID,Hemen way D. Rates of house hold gunshotownership and homicides across US regions and states,1881997.Am J Public health 2002;12:1988-93.

[4]. Chapman J, Milroy CM. Gunshot deaths in Yorkshire and humberside. Forensic Sci Int 1992;2:181-91

[5]. Bashir MZ, Saeed A,Khan D et al. Pattern of homicidal deaths in Faisalabad.J Ayub Med Coll Abbottabad 24;16(2):57-9

[6]. Muniu E,Katsivo Mn, Mwaura IW et al. Fatal non-tanspot injuries in Nairobi,Kenya. East Afr Med J 1994;7:346-349

[7]. Commentary: Firearms violence and Public health. Limiting the availability of guns. JAMA 1994;271:1281-1283.

[8]. Auckland city council. Our People website. Source fom statistic New Zealand, Census 2001.

[9]. Kohhneier RE Mcmahan CA,Dimaio VJM. Suicide b gunshot. AM J Forensic Med Pathol 2001;22 :337-40

[10]. WHO. injuries and violence Prevention department in small arms global health a contribution to weapons. July;2001.P. 920 .

[11]. Jain S,Singh R. Indian homemade gunshot. A technical review. Forensic Sci int 2004;144: 11-8.

[12]. Humayun M,Khan D,Zaman F, Khan J, Khan O et al. Analysis of homicidal deaths in district Di Khan: an autops study. J Ayub Med Coll Abbotta bad 2009;21(1):155-7

[13]. Krug EG,Powell KE,Dahlberg LL: Firearm-related deaths in the united States and 35 other high and upper middle income countries. Int.J. Epidemiol 1998,27: 214-221.

[14]. Houry D,Feldhaus KM,Nyquist SR,Abbott J,Pons PT. Emergency department documentation in cases of intestinal assault. Annals of emergency medicine 1999;34:715-719.

[15]. Archampong EQ.Wounds and wound healing.In: Badoe EA,Achampong EQ,da ocha-Afodu JT(EdS). Principles and Practice of Surgery in the tropics including Pathology in the tropics, $3^{\text {rd }}$ Edition. Ghana Publishing Corporation 2000:53-64.

[16]. Afuwape O,Alonge T. An Audit of gunshot injuries seen in the accident and emergency department of a Nigerian Tertiary hospital. West Afr J Med 2006;25:295-297.

[17]. Solagberu BA. Epidemiology and outcome of gunshot injuiesin a civilian Population in West Africa. European Journal of Trauma 2003;29(2):92-96.

[18]. A.Z Mohammed,ST Edino,O.Ochicha and A.B.Umar. Epidemiology of gunshot injuries in kano,Nigeria. Nigeria Journal of Surgical Research Vol 7 no3-4,2005:296-299.

[19]. Azam Khan Khetran,Samina Rehman,Zahirkhan,Mujeeb-ur-Rehman Baloch. Incidence of death due to gunshot injuies at district Barkhan, Balochistan. JLUMHS May-August 212; Vol 11: No.02.

[20]. Martins R,Siqurea M,Santos M et al> Prognostic Factors and treatment of Penetrating gunshot wounds to the head. Surg Neurol. 2003;60:98-104.

[21]. Emmanuel O.Ojo, Ahmed G,Ibrahim et al. Gunshot injuries in a North Eastern Nigeria Tertiary Hospital. Internet Journal of Surgery ISSN: $1528-8242$.

[22]. Falbo GH,Buzzetti R,Cattaneo A. Homicide in Children and adolescents: A case -Control Study in Recife,Brazil. Bulletin of the world health organization 2001;79:2-7. 